\title{
Sequence and preference in the use of electron acceptors in flooded agricultural soils**
}

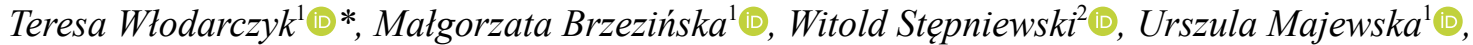 \\ Pawet Szarlip ${ }^{1}$, Alicja Księżopolska ${ }^{3}$, and Marek Pazur ${ }^{1}$ (D) \\ ${ }^{1}$ Institute of Agrophysics, Polish Academy of Sciences, Doświadczalna 4, 20-290 Lublin, Poland \\ ${ }^{2}$ Lublin University of Technology, Nadbystrzycka 40b, 20-618 Lublin, Poland \\ ${ }^{3}$ Department of Environmental Engineering Institute of Engineering and Technical Sciences Faculty of Exact Sciences and Health \\ Sciences, John Paul II Catholic University of Lublin, Konstantynów 1 H, 20-708 Lublin, Poland
}

Received August 24, 2020; accepted January 12, 2021

\begin{abstract}
Specifically, it was tested whether the presence of $\mathrm{O}_{2}$ in the headspace modified the sequence and preference of electron acceptor use under hypoxic conditions after prolonged drought in arable soils. This laboratory study was conducted in order to examine the use of electron acceptors: oxygen $\left(\mathrm{O}_{2}\right)$, nitrate $\left(\mathrm{NO}_{3}{ }^{-}\right)$and nitrous oxide $\left(\mathrm{N}_{2} \mathrm{O}\right)$, during aerobic and anaerobic respiration (denitrification). Agricultural soils (Typic Dystrudepts) classified as sandy, silty and loamy soils from arable top soils $(0-30 \mathrm{~cm})$ were used in the study. The change of oxidation states of different chemical species in the soil affected the use of electron acceptors during denitrification. The use of $\mathrm{O}_{2}$, $\mathrm{NO}_{3}{ }^{-}$and net $\mathrm{N}_{2} \mathrm{O}$ use was gradual and differed greatly among the soils. Furthermore, microorganisms were shown to be able to use all three investigated electron acceptors simultaneously, but with clearly visible preferences. The rate of electron acceptor use per day differentiated the investigated soils into a few different groups. Overall, the results of this study indicated that $\mathrm{N}_{2} \mathrm{O}$ was a more preferable electron acceptor than $\mathrm{NO}_{3}{ }^{-}$when $\mathrm{O}_{2}$ was present in the headspace for the most investigated soils. Moreover, a correlation existed between the final electron acceptor use and particle-size distribution and the native organic $\mathrm{C}$ content $\left(\mathrm{C}_{\mathrm{org}}\right)$. The rate of electron acceptor use per day calculated for $\mathrm{O}_{2}, \mathrm{NO}_{3}{ }^{-}$ and $\mathrm{N}_{2} \mathrm{O}$ may provide very important information for distinguishing the preference of electron acceptor use during aerobic and nitrate respiration in agroecosystems under hypoxic conditions after prolonged drought for different kinds of electron acceptor.

Keywords: electron acceptor use, $\mathrm{N}_{2} \mathrm{O}$ net use, $\mathrm{O}_{2}$ consumption, $\mathrm{NO}_{3}^{-}$reduction, flooded soils after drought
\end{abstract}

\footnotetext{
*Corresponding author e-mail: t.wlodarczyk@ipan.lublin.pl

**The paper was partly financed by project No. NN310115338 sponsored by Ministry of Science in Poland (2010-2013).
}

\section{INTRODUCTION}

The reduction of $\mathrm{O}_{2}$ and other oxidized inorganic redox components that serve as electron acceptors is generally sequential, with $\mathrm{O}_{2}$ being reduced first, followed by $\mathrm{NO}_{3}{ }^{-}$, $\mathrm{Mn}^{4+}, \mathrm{Fe}^{3+}, \mathrm{SO}_{4}{ }^{2-}$, and $\mathrm{CO}_{2}$ (Turn and Patrick, 1968). The content of soil oxidants in the soil which function as electron acceptors for organic matter degradation contributes significantly to these processes. The reduction of various oxidants in homogeneous soil suspensions occurs sequentially (Ponnamporuma, 1972). Nitrate is a key node in the network of the assimilatory and respiratory nitrogen pathways. For bacteria, it is both a nitrogen source and an electron acceptor. In agriculture, nitrate respiration by microorganisms is an important issue with respect to greenhouse gas emission (Kraft et al., 2011).

The highest $\mathrm{N}_{2} \mathrm{O}$ emissions primarily occur under hypoxic conditions characterized by a moderate $\mathrm{O}_{2}$ deficiency. The sequence of the reduction process that occurs under completely anoxic conditions $\left(\mathrm{N}_{2}\right.$ atmosphere) is consistent with thermodynamic theory, with soil $\mathrm{NO}_{3}^{-}$being reduced first, followed by $\mathrm{Mn}^{4+}$ and $\mathrm{Fe}^{3+}$, and finally $\mathrm{CO}_{2}$ to $\mathrm{CH}_{4}$. For as long as $\mathrm{O}_{2}$ is present in an adequate amount, other electron acceptors are relatively inactive, especially those that are more difficult to reduce (Vor et al., 2003). Dhamole et al. (2007) found that $\mathrm{NO}_{3}{ }^{-}$was preferred as an

(C) 2021 Institute of Agrophysics, Polish Academy of Sciences 
electron acceptor when both $\mathrm{NO}_{3}^{-}$and nitrite were available. Moreover, reduction processes have been reported to have a sequential nature, with one oxidized component not beginning to be reduced until all other oxidized components were completely reduced (Patrick and Jugsujinda, 1992). In many of the studies cited above, the authors concluded that the use of electron acceptors occurs: (i) in a strict sequence $\left(\mathrm{O}_{2}\right.$ being reduced first, followed by $\mathrm{NO}_{3}^{-}$, $\mathrm{Mn}^{4+}, \mathrm{Fe}^{3+}, \mathrm{SO}_{4}{ }^{2-}$, and $\mathrm{CO}_{2}$ ) and in accordance with thermodynamic theory, (ii) during the respiratory reduction chain of denitrification, which is typically $\mathrm{NO}_{3}{ }^{-} \rightarrow$ nitrite $\left(\mathrm{NO}_{2}{ }^{-}\right)$ $\rightarrow$ nitric oxide (NO) $\rightarrow \mathrm{N}_{2} \mathrm{O} \rightarrow \mathrm{N}_{2}$, (iii) under completely anoxic conditions soil $\mathrm{NO}_{3}^{-}$is reduced first and (iv) under a specific redox potential (Patrick and Jugsujinda, 1992; Vor et al., 2003). Several microbial processes compete for the available nitrate in the soil: denitrification, dissimilatory nitrate reduction to ammonium and anaerobic ammonium oxidation (Kraft et al., 2011). Kraft et al. (2011) demonstrated that knowledge concerning the mechanism of nitrate reduction in natural ecosystems is still lacking for the most part. Additionally, there is a lack of information pertaining to the sequence and preference of use when $\mathrm{O}_{2}, \mathrm{NO}_{3}{ }^{-}$ and $\mathrm{N}_{2} \mathrm{O}$ are available as electron acceptors in the soil during respiration under hypoxic conditions after prolonged drought. Therefore, it was decided to fill this research gap. We hypothesized that the presence of $\mathrm{O}_{2}$ in the headspace and the particle-size distribution in the soil would modify the sequence and affect the preference of electron acceptor use (EAu). To accomplish this, $\mathrm{O}_{2}, \mathrm{NO}_{3}{ }^{-}$, and $\mathrm{N}_{2} \mathrm{O}$ were analysed in agricultural soil samples after a prolonged drought, amended with $\mathrm{NO}_{3}{ }^{-}$and incubated under hypoxic conditions.

\section{MATERIALS AND METHODS}

Typic Dystrudepts (according to Soil Taxonomy) are classified as sandy soils (soil Nos 39, 224, 434, 772), silty soils (soil Nos. 922, 947, 951, 984) and loamy soils (soil Nos $328,342,351,543)$ from cultivated top soils $(0-30 \mathrm{~cm})$ were selected from the Soil Bank and the database of the Institute of Agrophysics, Polish Academy of Sciences in Lublin and used in the study (Bieganowski et al., 2013). The particle-size distribution was determined by using the sedimentation method and the distribution of particle sizes was expressed as a percentage (Öhlinger, 1995).

The soils tested showed wide variations in texture, $\mathrm{pH}$, organic $\mathrm{C}$ content, and native $\mathrm{NO}_{3}{ }^{-}$content (Table 1). Soil samples were collected from various agricultural Polish regions. Their basic properties and topography are presented in Table 1.

The bulk samples ( $5 \mathrm{~g}$ portions of air-dried soils) were sieved ( $1 \mathrm{~mm}$ sieve), placed in $38-\mathrm{cm}^{3}$ cylindrical glass vessels and enriched with $\mathrm{KNO}_{3}$ at a rate of $100 \mathrm{mg} \mathrm{NO}_{3}^{-}{ }^{-} \mathrm{N}$ $\mathrm{kg}^{-1}$ of dry soil, which corresponded approximately to 300 $\mathrm{NO}_{3}{ }^{-}-\mathrm{N} \mathrm{kg} \mathrm{ha}{ }^{-1}$ (calculated on a $20 \mathrm{~cm}$ layer basis). The soil:water ratio was approximately $1: 1(\mathrm{w}: \mathrm{w})$ with $0.5 \mathrm{~cm}$ of stagnant water on top of the soil surface. The vessels with soil suspensions were tightly sealed with rubber stoppers secured with metal caps which were fitted for gas sampling and incubated in an atmosphere of reduced $\mathrm{O}_{2}$ in relation to the air. Soil flooding and reduced $\mathrm{O}_{2}$ content in the headspace created hypoxia conditions in the investigated soils. The initial concentration of $\mathrm{O}_{2}$ in the gas headspace at the beginning of the incubation period was $10 \% \mathrm{v}: \mathrm{v} \pm 0.5$ (half of the air in the vessels was replaced with $\mathrm{N}_{2}$ ). Because the

Table 1. Basic properties, particle size distribution and topography of the Typic Dystrudepts investigation

\begin{tabular}{|c|c|c|c|c|c|c|c|c|}
\hline \multirow{3}{*}{$\begin{array}{l}\text { Parent } \\
\text { material }\end{array}$} & \multirow{3}{*}{$\begin{array}{l}\text { Texture } \\
\text { (Soil No.) }\end{array}$} & \multirow{3}{*}{ Topography } & \multicolumn{3}{|c|}{$\%$ of particle size fraction } & \multirow{3}{*}{$\begin{array}{c}\mathrm{C}_{\text {org. }} \\
\mathrm{g} \mathrm{kg}^{-1}\end{array}$} & \multirow{3}{*}{$\begin{array}{c}\mathrm{NO}_{3}{ }^{-}-\mathrm{N}_{0}{ }^{\mathrm{a}} \\
\mathrm{mg} \mathrm{kg}^{-1}\end{array}$} & \multirow{3}{*}{$\begin{array}{c}\mathrm{pH}_{0}{ }^{\mathrm{a}} \\
\text { in } \mathrm{H}_{2} \mathrm{O}\end{array}$} \\
\hline & & & $>0.05$ & $\begin{array}{l}0.05- \\
0.002\end{array}$ & $<0.002$ & & & \\
\hline & & & \multicolumn{3}{|c|}{$\mathrm{mm}$} & & & \\
\hline \multirow{4}{*}{ Sand } & Sand (39) ${ }^{\mathrm{b}}$ & Glacial plain & 95 & 5 & 0 & 6.7 & 4.53 & 4.69 \\
\hline & Sand (224) & Plain & 85 & 12 & 3 & 3.2 & 6.47 & 7.35 \\
\hline & Sand (434) & Glacial plain & 81 & 13 & 6 & 7.4 & 18.49 & 4.45 \\
\hline & Sand (772) & Glacial plain & 84 & 15 & 1 & 4.9 & 13.66 & 4.5 \\
\hline \multirow{4}{*}{ Silt } & Silty sand (922) & Mountainous terrain & 55 & 41 & 4 & 18.9 & 5.37 & 3.83 \\
\hline & Silty sand (947) & Mountainous terrain & 52 & 43 & 5 & 23.1 & 32.93 & 5.37 \\
\hline & Sandy silt (951) & Back of mountainous terrain & 32 & 60 & 8 & 28.5 & 65.76 & 3.94 \\
\hline & Sandy silt (984) & Hilly terrain & 27 & 67 & 6 & 12.4 & 7.87 & 4.71 \\
\hline \multirow{4}{*}{ Loam } & Loamy sand (328) & Light undulating terrain & 63 & 23 & 14 & 7.7 & 9.46 & 6.85 \\
\hline & Loamy sand (342) & Glacial plain & 74 & 21 & 5 & 4.4 & 29.94 & 7.38 \\
\hline & Loamy sand (351) & Glacial plain & 71 & 21 & 8 & 5.7 & 17.88 & 7.61 \\
\hline & Loamy sand (543) & Glacial plain & 69 & 28 & 3 & 8.8 & 9.78 & 5.56 \\
\hline
\end{tabular}

${ }^{a}$ Values from the start of incubation, ${ }^{b}$ soil number according to the Bank of Soil numeration and database of the Institute of Agrophysics, Polish Academy of Science, Lublin, Poland. 
stoppers were punctured several times, after each analysis, paraffin films were placed on the stoppers to ensure hermetic seals. Soil samples were incubated in triplicate at $20^{\circ} \mathrm{C}$ from 21 to 34 days depending on the type of soil.

Gas samples of the headspace atmosphere from each vessel were directly injected into a gas chromatograph (Shimadzu GC-14, Japan) and analysed for $\mathrm{N}_{2} \mathrm{O}$ and $\mathrm{O}_{2}$ after $1,2,3,7,10,14,21,28,32$ and 34 days of incubation. The $\mathrm{N}_{2} \mathrm{O}$ concentrations were determined using an electron capture detector (ECD) at an operating temperature of $300^{\circ} \mathrm{C}$ and a column oven temperature of $80^{\circ} \mathrm{C}$. The column packing material used for $\mathrm{N}_{2} \mathrm{O}$ detection was Porapak $\mathrm{Q}$. The $\mathrm{O}_{2}$ concentrations were determined using a thermal conductivity detector (TCD) at an operating temperature of $60^{\circ} \mathrm{C}$ and a column oven temperature of $40^{\circ} \mathrm{C}$. The column packing material used for $\mathrm{O}_{2}$ detection was Molecular Sieve 5A. Helium was used as a carrier gas for both detectors. The contents of $\mathrm{N}_{2} \mathrm{O}-\mathrm{N}$ and $\mathrm{O}_{2}$ were corrected for gas dissolved in water using Bunsen absorption coefficients (Gliński and Stepniewski, 1985). Additionally, the content of $\mathrm{O}_{2}$ was corrected for Ar by the subtraction of its content in the headspace.

A set of 360 incubation vessels was prepared for the soils (12 types of soils with 3 replicates and 10 sampling periods). One set of incubation vessels (36 vessels) was designed for gas analysis, while other sets were opened simultaneously for the analysis of their gas contents, to measure the $\mathrm{NO}_{3}{ }^{-}$content using an FIA Star 5000 autoanalyser - FOSS Tecator. Soil suspensions were quantitatively transferred into plastic flasks, shaken for $1 \mathrm{~h}$ with $250 \mathrm{ml}$ of $0.0125 \mathrm{~mol} \mathrm{~L}^{-1} \mathrm{CaCl}_{2}$, and then filtered through a filter paper, after which the extracts were analysed for $\mathrm{NO}_{3}{ }^{-} \mathrm{N}$ content. The organic $\mathrm{C}$ content was estimated based on the reduction of $\mathrm{Cr}_{2} \mathrm{O}_{7}^{2-}$ by organic matter, through the titration of unreduced $\mathrm{Cr}_{2} \mathrm{O}_{7}{ }^{2-}$ (Gajda et al., 2016). The $\mathrm{pH}$ of the $\mathrm{H}_{2} \mathrm{O}$ was determined using a pH-meter (PHM82 STANDARD pH METER Radiometer Copenhagen).

The results were presented as: (i) $\mathrm{O}_{2}, \mathrm{NO}_{3}{ }^{-}$and $\mathrm{N}_{2} \mathrm{O}$ content, $\left(\mathrm{mmol} \mathrm{kg}^{-1}\right)$ as a function of the incubation time for the soils developed from sand, silt and loam, (ii) and the rate of $\mathrm{O}_{2}$ consumption, $\mathrm{NO}_{3}{ }^{-}$reduction and $\mathrm{N}_{2} \mathrm{O}$ net use, presented as a percentage of the EAu value calculated in terms of mmol day ${ }^{-1}$ (the graphics compare the percentage part of each value to all categories).

Taking into consideration the oxydo-reductive conditions of the studied soils from the beginning to the end of the incubation period (from hypoxia to conditions close to anoxia), the $\mathrm{N}_{2} \mathrm{O}$ sources in the headspace could be due to the following processes: denitrification, nitrification, nitrifier denitrification and nitrate denitrification (Baggs, 2008). A clear loss of nitrates would indicate the predominance of denitrification. An additional source of nitrates in the initial phase of incubation could be nitrification (Baggs, 2008). The discussion of results below concerns the total pool of available $\mathrm{NO}_{3}^{-}$and $\mathrm{N}_{2} \mathrm{O}$ as electron acceptors, they are both utilized in the denitrification process.
Net $\mathrm{N}_{2} \mathrm{O}$ use by the soil will be observed if $\mathrm{N}_{2} \mathrm{O}$ reduction exceeds $\mathrm{N}_{2} \mathrm{O}$ production (Chapuis-Lardy et al., 2007).

The results were subjected to a regression analysis using linear $(y=a+b x)$, and logarithmic $(y=a \ln x+b)$ models. In each case, the model with the highest $R^{2}$ value was selected as the best fit for the experimental data. All analyses were conducted using Microsoft Office Excel 2007. A one-way analysis of variance (LSD test) was used to test the significance of the effect of soil texture on the $\mathrm{NO}_{3}{ }^{-}: \mathrm{N}_{2} \mathrm{O}$ ratio calculated for the day of the beginning of net $\mathrm{N}_{2} \mathrm{O}$ use from the headspace. The statistical analysis was performed using Statgraphics Centurion XVI.

\section{RESULTS}

The percentage of the EAu value produced by the process of microbial respiration under the conditions of hypoxia and anoxia were calculated in terms of mmol day ${ }^{-1}$. In order to illustrate the dynamics of EAu expressed in terms of $\mathrm{mmol} \mathrm{kg}^{-1}$ as a function of the incubation time for the investigated soils (Figs 1-6).

An evaluation of the $\mathrm{O}_{2}$ and $\mathrm{NO}_{3}^{-}$ratio revealed that $\mathrm{O}_{2}$ rather than $\mathrm{NO}_{3}{ }^{-}$was predominantly used on day 1 of the incubation with a varied efficiency in all of the soils used (Figs 1-6). Over the time period of the next day of incubation, $\mathrm{O}_{2}$ was used with a higher degree of efficiency than $\mathrm{NO}_{3}{ }^{-}$in the three sandy and silty soils with the exception of soil Nos 772 and 947 (Figs 1 and 3), while in loamy soils $\mathrm{NO}_{3}^{-}$was used which had a higher degree of efficiency than $\mathrm{O}_{2}$ (Fig. 5). After two days of incubation in all investigated soils, the dominance of $\mathrm{NO}_{3}^{-}$utilization was observed although the $\mathrm{O}_{2}$ concentration in the headspace of some soils was still relatively high, especially in some sandy and loamy soils, for example, on the second day of incubation the concentration of $\mathrm{O}_{2}$ was $16.6 \mathrm{mmol} \mathrm{kg}^{-1}$ which corresponded to $6.4 \%$ vol., and the $\mathrm{NO}_{3}^{-}$content was $7.7 \mathrm{mmol} \mathrm{kg}^{-1}$ for soil No. 772 . The $\mathrm{O}_{2}$ concentration was $16.5 \mathrm{mmol} \mathrm{kg}^{-1}$ corresponding to $6.3 \%$ vol., and the $\mathrm{NO}_{3}{ }^{-}$content was $2.6 \mathrm{mmol} \mathrm{kg}^{-1}$ for soil No. 328 (Figs 1, 2, 5, and 6). Between day 3 and 14, all of the available $\mathrm{NO}_{3}{ }^{-}$was used in all silty soils (Figs 3 and 4 ) and in the 2 loamy soils this occurred between day 7 and 28 (Figs 5 and 6) at that point $\mathrm{O}_{2}$ use increased in some soils. The dominance of $\mathrm{NO}_{3}^{-}$utilization was maintained for a few days, especially in some silty and loamy soils at various stages of incubation (Figs 3 and 6). During the following days of incubations the EAu values for the $\mathrm{O}_{2}$ and $\mathrm{NO}_{3}^{-}$ratio showed the value decreasing and increasing, depending on the type of soil being tested. During the first 3 days of incubation, the sandy, silty and loamy soils used an average of 53,79 and $72 \%$ of the available $\mathrm{O}_{2}$, while an average of 7,36 and $62 \%$, respectively of the available $\mathrm{NO}_{3}{ }^{-}$was consumed. 

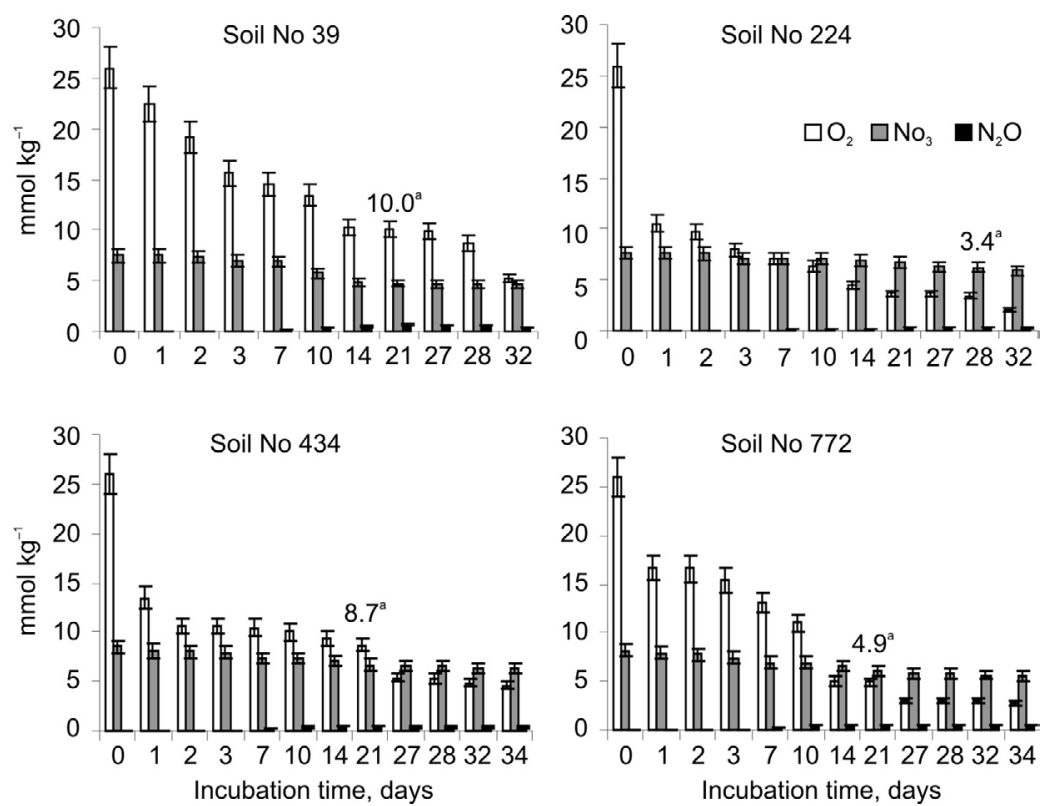

Fig. 1. Oxygen, nitrate and nitrous oxide content as a function of incubation time $\left(\mathrm{mmol} \mathrm{kg}^{-1}\right) ;{ }^{\mathrm{a}} \mathrm{O}_{2}$ concentration at which $\mathrm{N}_{2} \mathrm{O}$ consumption took place.
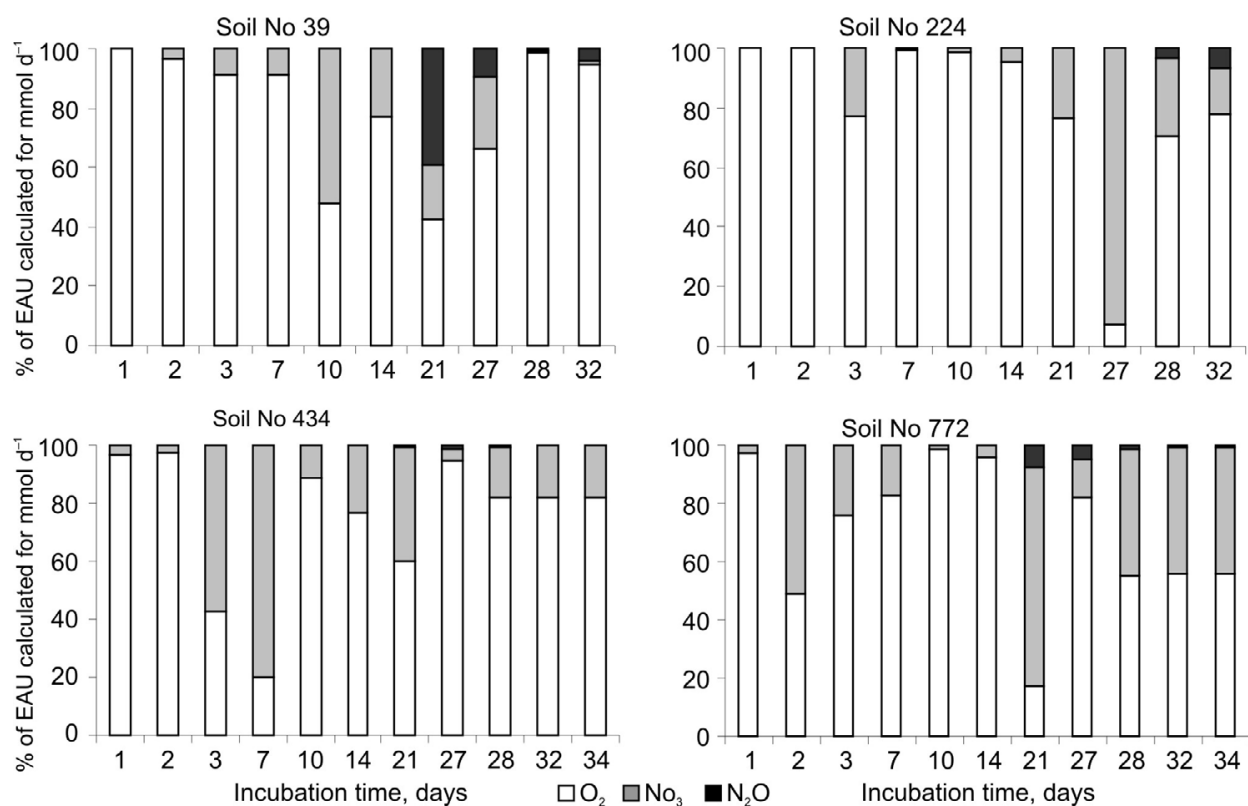

Fig. 2. Percentage of EAu in the process of microbial respiration in anoxia conditions calculated in terms of mmol day ${ }^{-1}$ in the sandy soils.

The net $\mathrm{N}_{2} \mathrm{O}$ use began between day 2 and day 28 of the incubation period, depending on the type of soil. The $\mathrm{N}_{2} \mathrm{O}$ content decreased in parallel with $\mathrm{O}_{2}$ presence in the headspace and differed greatly between the soils. The beginning of net $\mathrm{N}_{2} \mathrm{O}$ use which occurred in the presence of $\mathrm{O}_{2}$ in the headspace ranged from 3.4 to $10.0 \mathrm{mmol} \mathrm{kg}^{-1}$ for sandy soil corresponding to 1.3 to $3.9 \%$ vol., 1.0 to $6.9 \mathrm{mmol} \mathrm{kg}^{-1}$ for silty soils corresponding to 0.4 to $2.7 \%$ vol., and 3.1 to 16.5 $\mathrm{mmol} \mathrm{kg}{ }^{-1}$ and for loamy soils corresponding to 1.2 to $6.3 \%$ vol. (Figs 1-6). The EAu value for the $\mathrm{O}_{2}$ and $\mathrm{N}_{2} \mathrm{O}$ ratio, at the first day of net $\mathrm{N}_{2} \mathrm{O}$ use, showed that the amount of
$\mathrm{N}_{2} \mathrm{O}$ used was similar to the amount of $\mathrm{O}_{2}$ used in one of the sandy soils (No. 39), although the $\mathrm{O}_{2}$ concentration in the headspace was $10 \mathrm{mmol} \mathrm{kg}^{-1}$ corresponding to a $3.9 \%$ vol. and $\mathrm{N}_{2} \mathrm{O}$ was $0.6 \mathrm{mmol} \mathrm{kg}^{-1}$. In the rest of the soils, $\mathrm{O}_{2}$ was used by denitrifiers with a higher efficiency than $\mathrm{N}_{2} \mathrm{O}$. Over the following days of incubation, $\mathrm{N}_{2} \mathrm{O}$ was used with a higher efficiency than $\mathrm{O}_{2}$ in three silty soils Nos 922 , 951 and 984 on day 14th, 21st and 14th day of incubation, respectively and in one loamy soils (No. 351) on day 7 of 

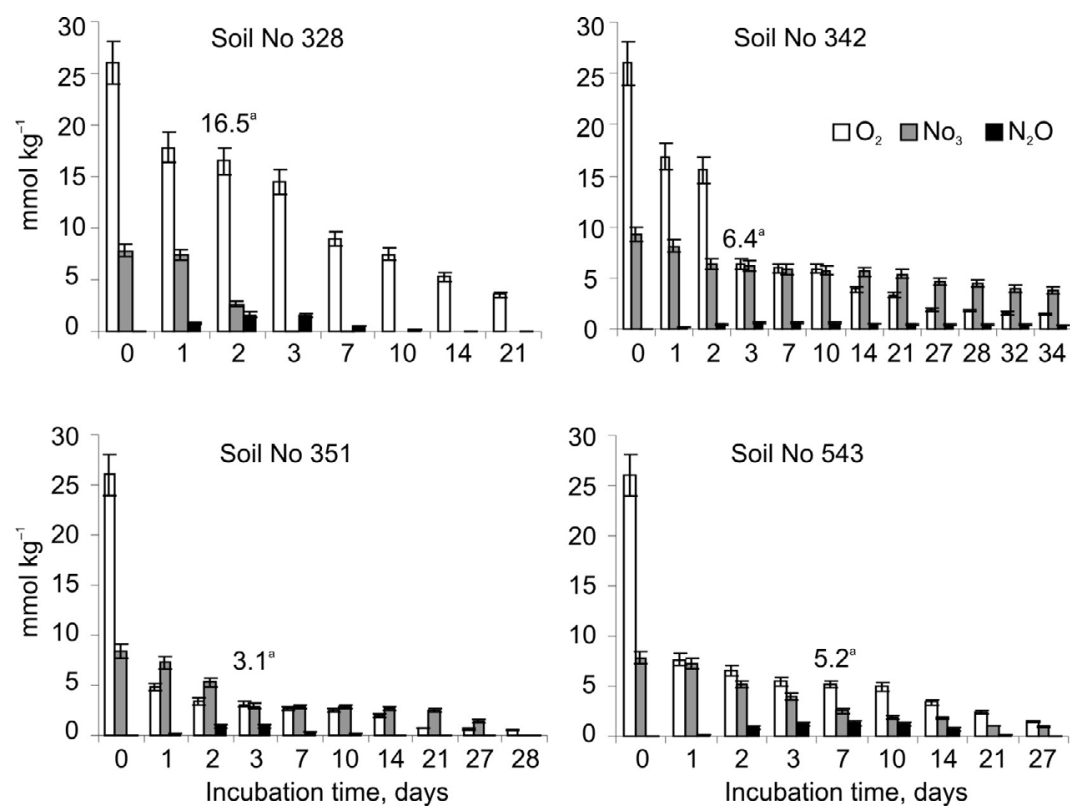

Fig. 3. Oxygen, nitrate and nitrous oxide content for silty soils as a function of incubation time $\left(\mathrm{mmol} \mathrm{kg}^{-1}\right)$; ${ }^{\mathrm{a}} \mathrm{O}_{2}$ concentration at which $\mathrm{N}_{2} \mathrm{O}$ consumption took place.
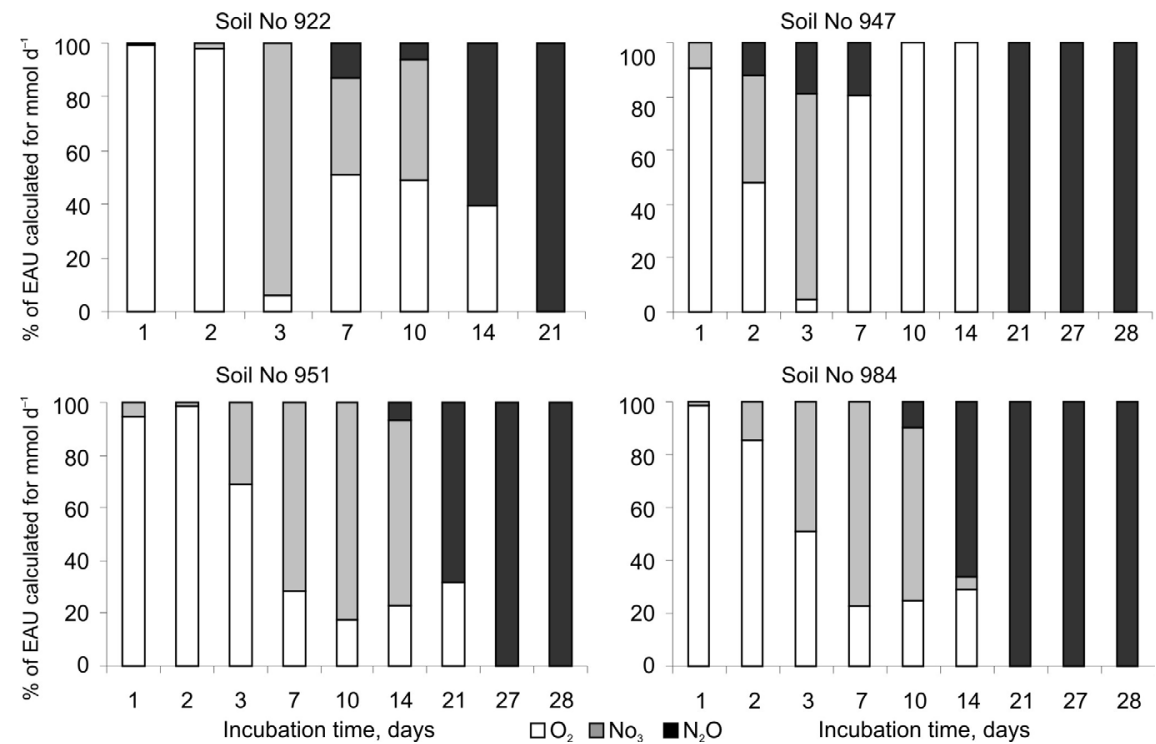

Fig. 4. Percentage of EAu in the process of microbial respiration in anoxia conditions calculated in terms of mmol day ${ }^{-1}$ in the silty soils.

incubation, where the $\mathrm{O}_{2}$ concentration in the headspace was $2.7 \mathrm{mmol} \mathrm{kg}^{-1}$ and $\mathrm{N}_{2} \mathrm{O}$ was $0.9 \mathrm{mmol} \mathrm{kg}^{-1}$ (Figs 1, 3, and 5).

Given the significant decrease in oxygen concentration after the first day of incubation and the low $\mathrm{pH}$ value of some soils, it was assumed with a high degree of probability that nitrification was not an additional source of $\mathrm{N}_{2} \mathrm{O}$ (Dinçer and Kargi, 2001) except for the first day of incubation.

The $\mathrm{N}_{2} \mathrm{O}$-net use began when the $\mathrm{NO}_{3}{ }^{-}$in the soil solution ranged from: 4.7 to $6.7 \mathrm{mmol} \mathrm{NO}_{3}{ }^{-} \mathrm{N} \mathrm{kg}^{-1}$, while the $\mathrm{N}_{2} \mathrm{O}$ content ranged from 0.4 to $0.6 \mathrm{mmol} \mathrm{N}_{2} \mathrm{O}-\mathrm{N} \mathrm{kg}^{-1}$, for the sandy soils. It ranged from 0.0 to $3.6 \mathrm{mmol} \mathrm{NO}_{3}{ }^{-} \mathrm{N}$ $\mathrm{kg}^{-1}$, and 1.4 to $2.4 \mathrm{mmol} \mathrm{N} \mathrm{N}_{2} \mathrm{O}-\mathrm{N} \mathrm{kg}^{-1}$ for the silty soils, and from 2.5 to $6.2 \mathrm{mmol} \mathrm{NO}_{3}^{-}-\mathrm{N} \mathrm{kg}^{-1}$ and 0.7 to $1.6 \mathrm{mmol}$ $\mathrm{N}_{2} \mathrm{O}-\mathrm{N} \mathrm{kg}^{-1}$ for the loamy soils (Figs 1-6). On the first day of net $\mathrm{N}_{2} \mathrm{O}$ use, $\mathrm{N}_{2} \mathrm{O}$ was used faster than $\mathrm{NO}_{3}{ }^{-}$in one of the sandy soils (No. 39) (Fig. 1), and in one of the loamy soils (No. 351) (Fig. 5), which implies that $\mathrm{N}_{2} \mathrm{O}$ was preferred as an electron acceptor in these soils. While in all silty soil net $\mathrm{N}_{2} \mathrm{O}$ use was more intensive after the exhaustion of the $\mathrm{NO}_{3}{ }^{-}$content in the soil solution (Fig. 3). 

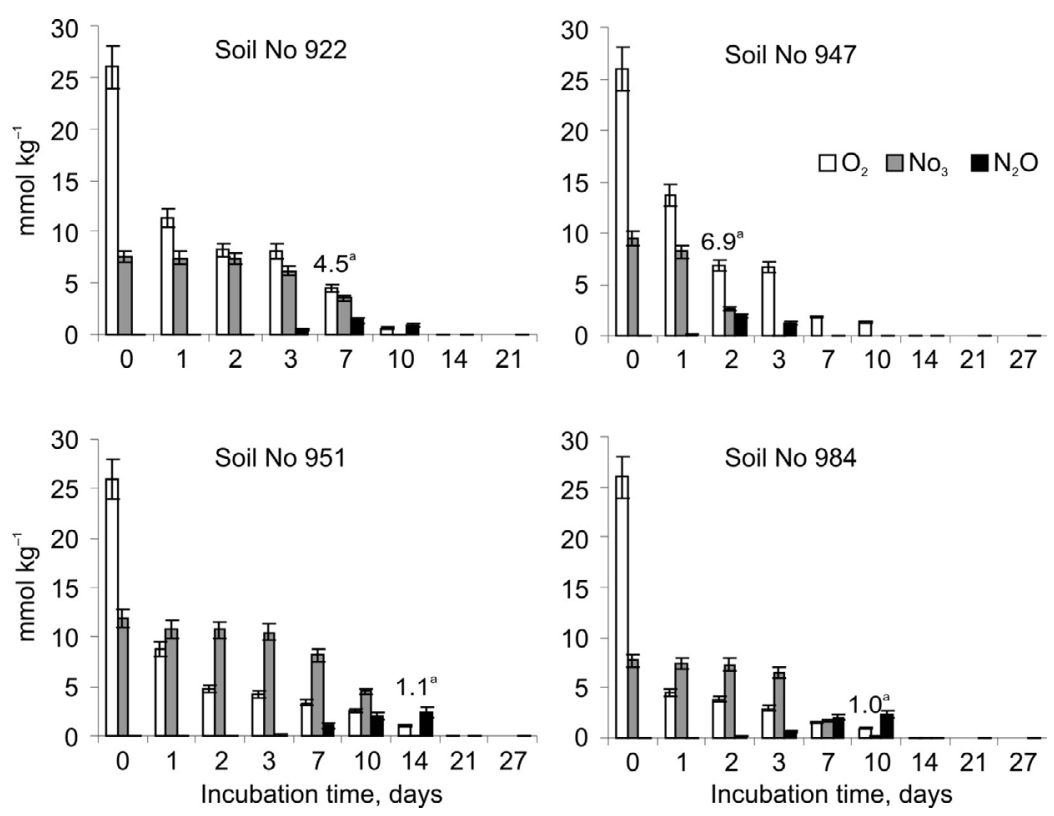

Fig. 5. Oxygen, nitrate and nitrous oxide content for loamy soils as a function of the incubation time $\left(\mathrm{mmol} \mathrm{kg}^{-1}\right)$; ${ }^{a} \mathrm{O}_{2}$ concentration at which $\mathrm{N}_{2} \mathrm{O}$ consumption took place.
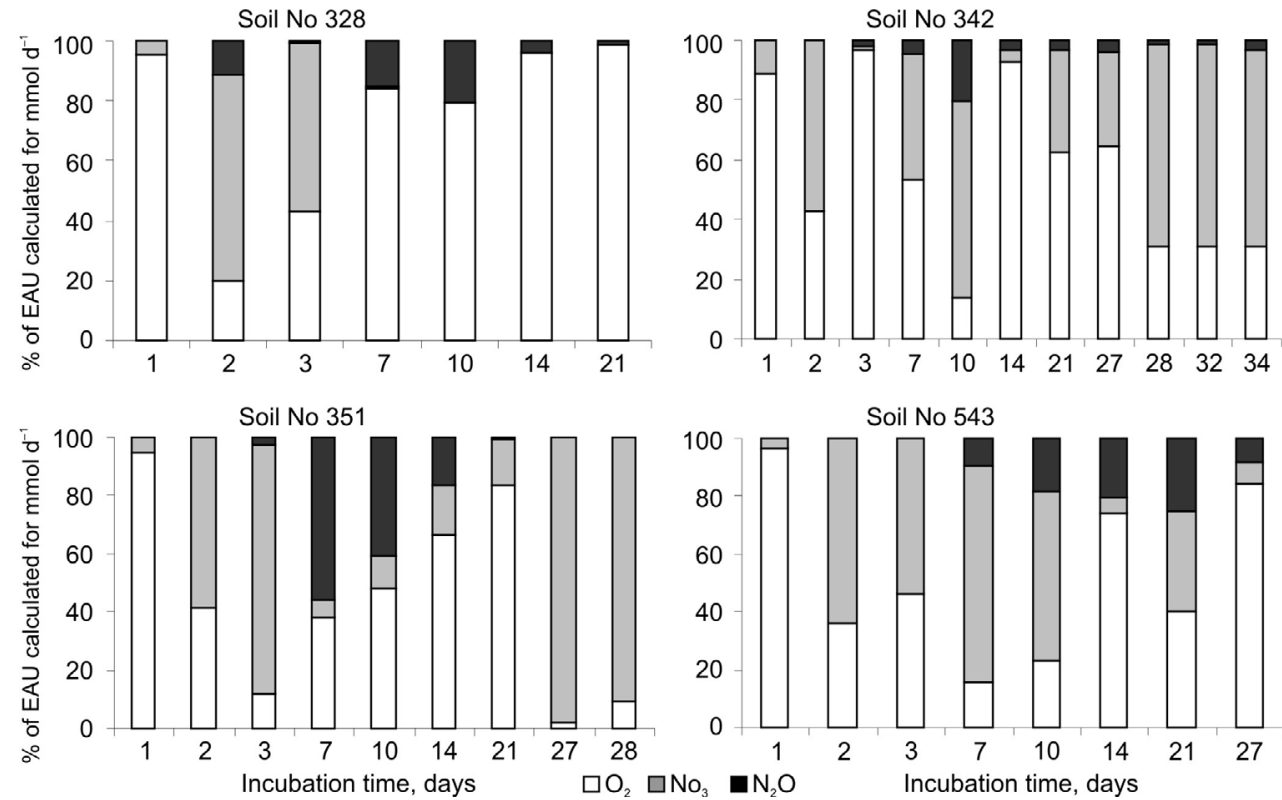

Fig. 6. Percentage of EAu in the process of microbial respiration in anoxia conditions calculated in terms of mmol day ${ }^{-1}$ in the loamy soils.

In summary, the average use of electron acceptors during the period under consideration depending on the particle-size distribution was as follows: $\mathrm{O}_{2}-86,100$ and $93 \%$ for the sandy, silty and loamy soils, respectively, $\mathrm{NO}_{3}{ }^{-}-29$, 100 and $87 \%$ for the sandy, silty and loamy soils, respectively, and $\mathrm{N}_{2} \mathrm{O}-28,100$ and $85 \%$ for the sandy, silty and loamy soils, respectively.

A correlation between the EAu and particle-size distribution (sand, silt and clay) of the soils was found. A negative correlation was found between all EAu values $\left(\mathrm{O}_{2}, \mathrm{NO}_{3}{ }^{-}\right.$ and $\mathrm{N}_{2} \mathrm{O}$ ) expressed as a percentage of the cumulative $\mathrm{EAu}$ values and the sand fraction ( $\mathrm{p}$ value ranging from $<0.01$ to $<0.001)$ and a positive correlation for the silt $(\mathrm{p}<0.001)$ and clay fraction except for $\mathrm{N}_{2} \mathrm{O}$ use $(\mathrm{p}<0.05$ and $<0.001)$ when all of the soils were compared to each other. These findings indicate that the use of $\mathrm{O}_{2}$ and $\mathrm{NO}_{3}^{-}$as electron acceptors under hypoxic conditions were correlated with sand, silt and clay fractions in the sandy, silty and loamy soils, and $\mathrm{N}_{2} \mathrm{O}$ in sandy and silty soils.

A slightly inferior relationship was observed between $\mathrm{NO}_{3}{ }^{-}$and $\mathrm{N}_{2} \mathrm{O}$ which was expressed as a percentage of the cumulative $\mathrm{EAu}$ value and the $\mathrm{C}_{\text {org }}$ for the soils analysed 
together $(\mathrm{p}<0.01)$, but no relationship was found between the percentage of $\mathrm{O}_{2}$ consumption and the content of the soil $\mathrm{C}_{\text {org }}$.

\section{DISCUSSION}

The rates of $\mathrm{O}_{2}, \mathrm{NO}_{3}{ }^{-}$and net $\mathrm{N}_{2} \mathrm{O}$ use may be controlled by the characteristics of the supply of electron acceptors, aeration states, particle-size distribution, organic $\mathrm{C}$ content and other conditions. The microorganisms used the three main available electron acceptors simultaneously e.g. $\mathrm{O}_{2}, \mathrm{NO}_{3}{ }^{-}$and $\mathrm{N}_{2} \mathrm{O}$ showing some degree of sequentiality and preference.

On the first day of incubation, the type and state of oxidation of electron acceptors appeared to be the most important factor affecting the sequence of their use during this experiment. All of the microorganisms $\mathrm{O}_{2}$ over $\mathrm{NO}_{3}{ }^{-}$as an electron acceptor. In general, the energy efficiency of aerobic respiration is much higher than that of anaerobic respiration (Gliński and Stępniewski, 1985). All sandy and loamy soils had more than one day when the microorganisms showed a preference for $\mathrm{O}_{2}$ over $\mathrm{NO}_{3}{ }^{-}$as an electron acceptor during different incubation stages. This means that a change in the preference of EAu over time was observed. Patrick et al. (1985) found that the composition of gases varies over time after flooding and is dependent on the soil and other environmental conditions. There are several possible explanations for the different preferences of EAu.

Firstly, $\mathrm{O}_{2}$ is a more energetically effective acceptor of electrons than $\mathrm{NO}_{3}{ }^{-}$. It is assumed that the denitrification process is less energetically favourable than the reduction of dissolved oxygen. In a system that contains oxygen, nitrate and organic $\mathrm{C}$, oxygen will normally be the preferred electron acceptor (Rivett et al., 2008).

Furthermore, the $5 \mathrm{~mm}$ of stagnant water above the soil did not limit the diffusion of $\mathrm{O}_{2}$ from the headspace to the soil suspension, and some of the $\mathrm{O}_{2}$ could be utilized by the organisms living at the border between them. The rate of disappearance of $\mathrm{O}_{2}$ reached a peak on the first day of incubation. The gradual decrease in the $\mathrm{O}_{2}$ use rate may be caused by the gradual decrease in $\mathrm{O}_{2}$ diffusion into the soil suspension with time and its lower availability. Cho (1982) investigated $\mathrm{O}_{2}$ consumption, as well as $\mathrm{N}_{2} \mathrm{O}$, and $\mathrm{N}_{2}$ production and found that the rates of $\mathrm{O}_{2}$ consumption changed over time.

Secondly, the results indicate the importance of particle-size distribution in the preference of EAu. According to the average EAu value for $\mathrm{O}_{2}$ and $\mathrm{NO}_{3}^{-}$, the highest $\mathrm{O}_{2}$ use was observed during the first 3 days of incubation in sandy soils $\left(53 \% \mathrm{O}_{2}: 7 \% \mathrm{NO}_{3}{ }^{-}=7.6\right)$, while it was used to a far lower extent in silty soils $\left(79 \% \mathrm{O}_{2}: 36 \% \mathrm{NO}_{3}{ }^{-}=2.2\right)$, and the value observed for loamy soils was close to one $\left(72 \% \mathrm{O}_{2}: 62 \% \mathrm{NO}_{3}{ }^{-}=1.2\right)$. These findings imply that the degree of $\mathrm{O}_{2}$ and $\mathrm{NO}_{3}{ }^{-}$use was only similar in loamy soils and was closely associated with particle-size distribution.
In general, over the following days of incubation $\mathrm{NO}_{3}^{-}$was utilized with a higher degree of activity by microorganisms than $\mathrm{O}_{2}$ and when almost all of the $\mathrm{NO}_{3}^{-}$was used, $\mathrm{O}_{2}$ use increased sharply. Particle-size distribution (especially the finer fraction) appeared to be one of the most important factors affecting the sequence of electron acceptors used. The results suggest that the particle-size distribution and organic $\mathrm{C}$ content rather than respiratory substrate availability appeared to be more important to the rate of $\mathrm{O}_{2}$ and $\mathrm{NO}_{3}^{-}$use during the following days of incubation. Johnson et al. (2012) suggested that the coupling between $\mathrm{C}$ and $\mathrm{N}$ in agricultural streams involves potentially complex interactions with sediment texture and organic matter. However, the relatively high organic $\mathrm{C}$ content (12.4-28.5 g $\mathrm{kg}^{-1}$ ) in silty soils appeared to play one of the main roles in determining the preference of $\mathrm{NO}_{3}{ }^{-}$use after day 2 of the incubation. Peterson et al. (2013) suggested that, with the input of the DOC substrate, alluvial gravel materials could generate enough enzyme during a 1-2 day anaerobic period to denitrify significant quantities of nitrate. Harrison-Kirk et al. (2013) stated that the soil organic matter (SOM) content is one of the important factors affecting carbon (C) and nitrogen $(\mathrm{N})$ mineralization under constant soil moisture. The intensive utilization of $\mathrm{O}_{2}$ at the beginning of the incubation period, when an average of $68 \%$ of the available $\mathrm{O}_{2}$ was used, stimulated the consumption of $\mathrm{NO}_{3}{ }^{-}$during denitrification under more suitable conditions for its reduction.

Among the soils with a lower $\mathrm{C}_{\text {org }}$ content, a second period of intensive $\mathrm{O}_{2}$ use, which was not related to decreasing $\mathrm{NO}_{3}^{-}$use caused by a lower $\mathrm{NO}_{3}{ }^{-}$availability, was noted. One exception was loamy soil No. 328, where the highest content of the finest fraction (particle size $<0.002-14 \%$ ), rather than $\mathrm{O}_{2}$ availability and organic $\mathrm{C}$ content $(7.7 \mathrm{~g}$ $\mathrm{kg}^{-1}$ ), may be the cause of the very intensive $\mathrm{NO}_{3}^{-}$use and subsequent $\mathrm{O}_{2}$ consumption after the exhaustion of $\mathrm{NO}_{3}{ }^{-}$. Soil No. 328 had the lowest starting value of Eh $(+229 \mathrm{mV})$, indicating that it was likely to be more susceptible to reduction under field conditions, resulting in a greater degree of adaptation to the respiration of $\mathrm{NO}_{3}{ }^{-}$ compared to other soils. Włodarczyk et al. (2011) stated that the percentage of clay in the soil is one of the most significant determining factors for the rate of $\mathrm{NO}_{3}^{-}$reduction.

Finally, for silty soils with a higher $\mathrm{C}_{\text {org }}$ content, there was an absence of any second period of predominant $\mathrm{O}_{2}$ consumption because the use of $\mathrm{NO}_{3}{ }^{-}$was higher than that of $\mathrm{O}_{2}$ until it disappeared completely from the soil solution. Bonin and Michotey, (2006) measured the denitrification rates and found complete $\mathrm{NO}_{3}^{-}$use during the first hour of incubation.

$\mathrm{N}_{2} \mathrm{O}$ was the third electron acceptor source that was used from the headspace, although $\mathrm{O}_{2}$ and $\mathrm{NO}_{3}{ }^{-}$were still available.

The EAu ratio for $\mathrm{O}_{2}$ and $\mathrm{N}_{2} \mathrm{O}$ showed that $\mathrm{O}_{2}$ was preferred over $\mathrm{N}_{2} \mathrm{O}$ as an electron acceptor at the beginning of the period of net $\mathrm{N}_{2} \mathrm{O}$ use, except for one of the sandy soils 
where the use of both acceptors was comparable (No. 39). During the following days of incubation in three silty soils (Nos 922, 951 and 984) and one loamy soil (No. 351) $\mathrm{N}_{2} \mathrm{O}$ was utilized more efficiently than $\mathrm{O}_{2}$.

There are several possible explanations for this phenomenon. One is that there may be an additional branch in the transfer of electron acceptors which is transiently used under hypoxic environmental conditions. Some groups of denitrifiers are capable of using both $\mathrm{O}_{2}$ and $\mathrm{NO}_{3}{ }^{-}$or nitrite as the electron acceptor simultaneously (Carter et al., 1995). Therefore, denitrification by those organisms may occur under aerobic conditions if a rate-limiting step in the transfer of electrons from its substrate to $\mathrm{O}_{2}$ is present. The provision of a second electron acceptor, in this case $\mathrm{NO}_{3}{ }^{-}$, enables the utilization of an additional branch in the electron transport chain (Robertson and Kuenen, 1991). These findings indicate that the provision of a second electron acceptor, in this case $\mathrm{N}_{2} \mathrm{O}$, allows for the utilization of an additional branch in the electron transport chain, as is the case with $\mathrm{NO}_{3}^{-}$. Therefore, the presence of $\mathrm{O}_{2}$ in the headspace changed the aeration status of the studied system when compared to anaerobic conditions and, as a consequence, the sequence of electron acceptors used. Johnson et al. (2012) suggested that coupling between $\mathrm{C}$ and $\mathrm{N}$ in agricultural streams involves potentially complex interactions and possibly indirect biogeochemical pathways.

A second explanation may be $\mathrm{N}_{2} \mathrm{O}$ being consumed more rapidly than $\mathrm{O}_{2}$, resulting from the depletion of the $\mathrm{O}_{2}$ concentration to a certain level in the headspace and a decreased rate of supply to the soil suspension. The greater rate of net use of $\mathrm{N}_{2} \mathrm{O}$ compared to that of $\mathrm{O}_{2}$ may be due to greater $\mathrm{N}_{2} \mathrm{O}$ solubility in water and a higher concentration and accessibility, especially in the later part of the incubation when the $\mathrm{O}_{2}$ concentration was very low. However, when the $\mathrm{N}_{2} \mathrm{O}$ content in the headspace decreased to a certain level, $\mathrm{O}_{2}$ was again utilized to a higher degree than $\mathrm{N}_{2} \mathrm{O}$ (soils No. 947).

The uniqueness of soil No. 351 should be emphasized. On the seventh day of incubation, net $\mathrm{N}_{2} \mathrm{O}$ use was observed, at the same time the utilization of $\mathrm{O}_{2}$ and $\mathrm{NO}_{3}^{-}$ as an electron acceptor clearly declined. Over the next 7 days, intense net $\mathrm{N}_{2} \mathrm{O}$ use was observed. On day 21 of the incubation, when the $\mathrm{N}_{2} \mathrm{O}$ concentration dropped to 0.01 mmol N $\mathrm{N}_{2} \mathrm{O}-\mathrm{N} \mathrm{kg}^{-1}, \mathrm{O}_{2}$ and $\mathrm{NO}_{3}^{-}$utilization increased sharply, thereby indicating that this soil preferably utilized $\mathrm{N}_{2} \mathrm{O}$ as opposed to the remaining two electron acceptors. The results contradict the study of Chapuis-Lardy et al. (2007), which stated that denitrifiers use $\mathrm{N}_{2} \mathrm{O}$ as an electron acceptor and reduce it to $\mathrm{N}_{2}$ when soil nitrate concentrations are very low.

The use of electrons to change the state of oxidation, i.e. from more oxidized to less oxidized, may have been the result of the microbial community structure and activity of the investigated soil, the genetic configuration of $\mathrm{N}_{2} \mathrm{O}$ reductase, or the history of the soil prior to sampling (i.e. the oxygenation status of the soil, availability of $\mathrm{NO}_{3}^{-}$, humidity, crop production and rotation, etc.). The history of the soil prior to sampling and the prolonged drought before flooding may have caused differences in the species composition of the denitrifying community and affected the preferences in the use of electron acceptors. The respiratory reduction chain of denitrification depends on the environmental conditions or genetic configuration (Dodla et al., 2008; Philippot et al., 2011; Pauleta et al., 2013; Hatano, 2019). Johnson et al. (2012) suggested that coupling between $\mathrm{C}$ and $\mathrm{N}$ in agricultural streams involves potentially complex interactions with the microbial community structure, and may also involve indirect biogeochemical pathways. Bouwman et al. (2002) reported that limited information was available with regard to the bulk reduction of $\mathrm{N}_{2} \mathrm{O}$ to $\mathrm{N}_{2}$ by $\mathrm{N}_{2} \mathrm{O}$-reductase, which was regulated by various soil and environmental factors. $\mathrm{N}_{2} \mathrm{O}$ reductase has been isolated in different forms depending on the oxidation state and molecular forms of its $\mathrm{Cu}$ centres (Pauleta et al., 2013). Furthermore, soil microorganisms maintain their microbiological activity (capacity for memory) for many years from the time of sampling agricultural soils (Włodarczyk, 2000).

Thirdly, in some soils under consideration, an additional result of preferential $\mathrm{O}_{2}$ use versus $\mathrm{NO}_{3}{ }^{-}$was observed at the time at which $\mathrm{N}_{2} \mathrm{O}$ began to be used from the headspace, resulting from the fact that $\mathrm{N}_{2} \mathrm{O}$ uses the same biochemical pathway as $\mathrm{NO}_{3}{ }^{-}$, and this led to the following reaction: $\left(\mathrm{N}_{2} \mathrm{O} \rightarrow \mathrm{N}_{2}\right)$. Moreover, in this case a synergistic effect occurred resulting from the simultaneous use of $\mathrm{O}_{2}$ and $\mathrm{N}_{2} \mathrm{O}$. The lower concentration of $\mathrm{O}_{2}$ creates improved conditions for the production of $\mathrm{N}_{2} \mathrm{O}$ reductase, which is particularly sensitive to the presence of $\mathrm{O}_{2}$ (Włodarczyk et al., 2011).

The initiation of net $\mathrm{N}_{2} \mathrm{O}$ utilization was observed simultaneously with $\mathrm{NO}_{3}{ }^{-}$consumption when the $\mathrm{NO}_{3}{ }^{-}-\mathrm{N}$ concentration (mmol kg-1 of soil) in the soil solution was much higher than that of $\mathrm{N}_{2} \mathrm{O}-\mathrm{N}$. The average concentration of $\mathrm{NO}_{3}{ }^{-} \mathrm{-N}$ at the start of net $\mathrm{N}_{2} \mathrm{O}$ use was 5.9, 2.3 and $3.6 \mathrm{mmol} \mathrm{kg}^{-1}$, and $\mathrm{N}_{2} \mathrm{O}-\mathrm{N}$ was $0.5,1.8$ and $1.1 \mathrm{mmol} \mathrm{kg}^{-1}$ in the case of sandy, silty and loamy soils, respectively.

A one-way analysis of variance (LSD test) showed the significance of the effect of soil texture on the $\mathrm{NO}_{3}{ }^{-}: \mathrm{N}_{2} \mathrm{O}$ ratio which was calculated from the day of the initiation of net $\mathrm{N}_{2} \mathrm{O}$ use from the headspace. There were differences between the sandy soils (coarse-grained soils) and silty and loamy soils (fine-grained soils). The high ratio of $\mathrm{NO}_{3}{ }^{-}: \mathrm{N}_{2} \mathrm{O}$ in sandy soils (12.2) compare to silty (3.6) and loamy (1.7) soils should be noted. In sandy soils, which had better aeration, $\mathrm{N}_{2} \mathrm{O}$ reductase was probably less adapted to hypoxic conditions in the soil under natural conditions as compared to the fine-grained soils. Bouwman et al. (2002) reported that $\mathrm{N}_{2} \mathrm{O}$ reductase has been isolated in different forms depending on the oxidation state and molecular forms of its $\mathrm{Cu}$ centres. 
In general, the statistical analysis clearly shows a correlation between the EAu value and particle-size distribution (sand, silt and clay) of soils, this is particularly the case with silty soils $(\mathrm{p}<0.001)$. Liptzin et al. (2011) investigated humid tropical forest soils and found a correlation between the content of $\mathrm{O}_{2}$ and $\mathrm{N}_{2} \mathrm{O}$. Harrison-Kirk et al. (2013) found that soil texture was one of the important factors affecting nitrogen $(\mathrm{N})$ mineralization under constant soil moisture conditions.

Based on the ratio of $\mathrm{NO}_{3}{ }^{-}$and $\mathrm{N}_{2} \mathrm{O}$ utilization, soils may be divided into two groups: (i) those for which the beginning of net $\mathrm{N}_{2} \mathrm{O}$ use occurs at low levels of $\mathrm{NO}_{3}^{-}$or after their complete consumption and (ii) those which show a preference for the use of $\mathrm{N}_{2} \mathrm{O}$ (the less oxidized compound) as an electron acceptor with a simultaneously high content of $\mathrm{NO}_{3}^{-}$(the more highly oxidized compound) in the soil solution.

The first group included two silty soils. The net $\mathrm{N}_{2} \mathrm{O}$ use in the two soils started when the $\mathrm{NO}_{3}{ }^{-}-\mathrm{N}$ concentration was below one and where $\mathrm{N}_{2} \mathrm{O}$ use was observed after the complete consumption of $\mathrm{NO}_{3}^{-}$.

When the ratio of $\mathrm{NO}_{3}^{-}$and $\mathrm{N}_{2} \mathrm{O}$ use for the second group were considered, it was found that the net $\mathrm{N}_{2} \mathrm{O}$ use in these soils was initiated when the $\mathrm{NO}_{3}^{-}-\mathrm{N}$ concentration was above 1.0 and ranged from 2.5 to $6.65 \mathrm{mmol} \mathrm{kg}^{-1}$ while the concentration of $\mathrm{N}_{2} \mathrm{O}$ ranged from 0.41 to $2.4 \mathrm{mmol} \mathrm{kg}^{-1}$. These findings indicate that the appearance of $\mathrm{N}_{2} \mathrm{O}$ as an electron acceptor even at relatively low content, may limit $\mathrm{NO}_{3}{ }^{-}$use in some soils. The sequence of electron acceptors used in the soils described above is consistent with the sequence described in several other studies. Specifically, Cho and Sadkinan, (1978) reported that the effect of $\mathrm{NO}_{3}{ }^{-}$ upon the reduction of $\mathrm{N}_{2} \mathrm{O}$ to $\mathrm{N}_{2}$ was due to the competition between $\mathrm{NO}_{3}{ }^{-}$and $\mathrm{N}_{2} \mathrm{O}$ as electron acceptors. Glatzel and Stahr, (2001) found that a soil medium with a low content of $\mathrm{NO}_{3}^{-}$acted as an $\mathrm{N}_{2} \mathrm{O}$ sink because $\mathrm{NO}_{3}{ }^{-}$is preferred over $\mathrm{N}_{2} \mathrm{O}$ as an electron acceptor. Wagner-Riddle et al. (1997) and Ryden (1983) also connected the events of $\mathrm{N}_{2} \mathrm{O}$ uptake to low soil $\mathrm{NO}_{3}{ }^{-}$concentration. Vor et al. (2003) stated that the final step of denitrification (the reduction of $\mathrm{N}_{2} \mathrm{O}$ to $\mathrm{N}_{2}$ ) would not occur so long as more efficient electron acceptors $\left(e . g . \mathrm{NO}_{3}{ }^{-}\right)$were still available. Finally, Włodarczyk et al. (2004) investigated the stability of $\mathrm{NO}_{3}^{-}$ in agricultural soils under hypoxic conditions and found that $\mathrm{N}_{2} \mathrm{O}$ could be used as an electron acceptor in the presence of low and moderate $\mathrm{NO}_{3}{ }^{-}$concentrations, while the presence of $\mathrm{NO}_{3}^{-}$at concentrations greater than $100 \mathrm{mg}$ $\mathrm{NO}_{3}{ }^{-} \mathrm{N} \mathrm{kg}^{-1}$ inhibited the consumption of $\mathrm{N}_{2} \mathrm{O}$ by the loess soils. When the headspace- $\mathrm{N}_{2} \mathrm{O}$ dropped slightly to a value less than $0.5 \mathrm{mmol} \mathrm{N} \mathrm{kg}{ }^{-1}$ and distinctly dropped in soil No. $351\left(0.01 \mathrm{mmol} \mathrm{N} \mathrm{kg}^{-1}\right)$ and the $\mathrm{NO}_{3}^{-}-\mathrm{N}$ concentration was still comparably high (an average value was 4.6 mmol N kg$\left.{ }^{-1}\right), \mathrm{NO}_{3}^{-}$utilization increased sharply. As stated above, $\mathrm{NO}_{3}{ }^{-}$inhibited the reduction of $\mathrm{N}_{2} \mathrm{O}$ to $\mathrm{N}_{2}$, but in this case, the appropriate conditions for the investigation of this statement may not apply. In general, under hypoxic conditions, an alternative sequence of electron acceptor preference was noted. Specifically, net $\mathrm{N}_{2} \mathrm{O}$ utilization was not limited by the relatively high or very high $\mathrm{NO}_{3}{ }^{-}$content in the soil solution. This was because, in the case of these soils, $\mathrm{N}_{2} \mathrm{O}$ was a more preferable electron acceptor than $\mathrm{NO}_{3}^{-}$, especially at the beginning of the $\mathrm{N}_{2} \mathrm{O}$ disappearance from the headspace. The exceptions to this were two silty soils No. 951 and 984 , which showed a decrease in $\mathrm{NO}_{3}^{-}$concentration to 0.0 and $0.15 \mathrm{mmol} \mathrm{N}-\mathrm{NO}_{3}^{-} \mathrm{kg}^{-1}$ in the soil solution, thereby indicating that the low level of $\mathrm{NO}_{3}{ }^{-}$may have limited its availability and affected the preference for $\mathrm{N}_{2} \mathrm{O}$ use. In some soils, the low $\mathrm{O}_{2}$ concentration in the headspace probably had a greater effect on the net use of $\mathrm{N}_{2} \mathrm{O}$ as opposed to $\mathrm{NO}_{3}^{-}$. Specifically, these conditions probably resulted in the activation of $\mathrm{N}_{2} \mathrm{O}$ reductase, which is extremely sensitive to $\mathrm{O}_{2}$, rather than high concentrations of $\mathrm{NO}_{3}^{-}$. In the other soils, the preferential net use of $\mathrm{N}_{2} \mathrm{O}$ or $\mathrm{NO}_{3}^{-}$might have been due to the microbial activity of the investigated soil, the genetic configuration of $\mathrm{N}_{2} \mathrm{O}$ reductase, and the history of the soil prior to sampling, in particular the oxygenation status of the soil before sampling.

One very important finding of this study was that, during $\mathrm{NO}_{3}^{-}$use, $\mathrm{N}_{2} \mathrm{O}$ was a preferable electron acceptor compared to $\mathrm{NO}_{3}{ }^{-}$when $\mathrm{O}_{2}$ was present in the headspace for most of the investigated agricultural soils. Accordingly, even when there is a relatively high concentration of $\mathrm{NO}_{3}{ }^{-}$ in the soil suspension a higher net $\mathrm{N}_{2} \mathrm{O}$ use compared to $\mathrm{NO}_{3}{ }^{-}$use may be expected. These findings indicate that, in the natural agricultural soil environment, under conditions that are satisfactory for denitrification, intensive net $\mathrm{N}_{2} \mathrm{O}$ utilization can occur during its migration from the deeper parts of the profile to the atmosphere when there are high concentrations of $\mathrm{NO}_{3}^{-}$present. Zaman and Nguyen, (2010) found that, unlike $\mathrm{N}_{2} \mathrm{O}$, the emission of $\mathrm{N}_{2}$ to the atmosphere does not pose any environmental problems and it can be recycled through symbiotic and non-symbiotic $\mathrm{N}_{2}$ fixation.

\section{CONCLUSIONS}

1. Considering the sequence of electron acceptor use, the microorganisms showed some preferences in the use of electron acceptors.

2. The results showed that the use of products during $\mathrm{NO}_{3}{ }^{-}$reduction which occurred under hypoxic conditions did not follow the pattern of the sequence which occurs during denitrification: $\mathrm{NO}_{3}{ }^{-} \rightarrow \mathrm{NO}_{2}^{-} \rightarrow \mathrm{NO} \rightarrow \mathrm{N}_{2} \mathrm{O} \rightarrow \mathrm{N}_{2}$, (under completely anoxic conditions).

3. It is likely that the presence of $\mathrm{O}_{2}$ in the headspace changed the oxygenation status of the studied system and, as a consequence, the sequence of electron acceptors used, especially in the case of $\mathrm{NO}_{3}^{-}$and $\mathrm{N}_{2} \mathrm{O}$ use.

4. The calculated percentage of EAu confirms that the particle-size distribution had a significant impact on preferences in the use of electrons in the process of nitrate respiration. 
5. The electron acceptors, which had a higher degree of oxidation $\left(\mathrm{O}_{2}, \mathrm{NO}_{3}{ }^{-}\right)$are used more effectively in soils with coarser particle sizes, but the increase in fine fraction (clay) caused a significant increase in the use of electron acceptors, with a lower degree of oxidation $\left(\mathrm{N}_{2} \mathrm{O}\right)$.

6. Taking into account $\mathrm{N}_{2} \mathrm{O}$ emissions, fine-grained soils are less of a threat to the environment.

Conflict of interest: The authors declare no conflict of interest.

\section{REFERENCES}

Baggs E.M., 2008. A review of stable isotope techniques for $\mathrm{N}_{2} \mathrm{O}$ source partitioning in soils: Recent progress, remaining challenges and future considerations. Rapid Commun. in Mass Spectrom., 22, 1664-1672. https://doi.org/10.1002/ rcm.3456

Bieganowski A., Witkowska-Walczak B., Gliński J., Sokołowska Z., Sławiński C., Brzezińska M., and Włodarczyk T., 2013. Database of Polish arable mineral soils: a review. Int. Agrophys., 27, 335-350.

https://doi.org/10.2478/intag-2013-0003

Bonin P.C. and Michotey V.D., 2006. Nitrogen budget in a microbial mat in the Camargue (southern France). Mar. Ecology-Progress Series, 322, 75-84. https://doi.org/10.3354/meps322075

Bouwman A.F., Boumas L.J.M., and Batjes N.H., 2002. Emissions of $\mathrm{N}_{2} \mathrm{O}$ and $\mathrm{NO}$ from fertilized fields: Summary of available measurement data. Global Biogeochem. Cycles, 16, 1-13. https://doi.org/10.1029/2001gb001811

Carter J.P., Hsiao Y.H., Spiro S., and Richardson D.J., 1995. Soil and sediment bacteria capable of aerobic nitrate respiration. Appl. Environ. Microbiol., 61, 2852-2858. https:// doi.org/10.1128/aem.61.8.2852-2858.1995

Chapuis-Lardy L., Wrage N., Metay A., Chotte, J-L., and Bernoux M., 2007. Soils, a sink for $\mathrm{N}_{2} \mathrm{O}$ ? A review. Global Change Biol., 13, 1-17. https://doi.org/10.1111/j.1365-2486.2006.01280.x

Cho C.M., 1982. Oxygen consumption and denitrification kinetics in soil. Soil Sci. Soc. Am. J., 46, 756-762.

Cho C. M. and Sadkinan L., 1978. Mass spectrometric investigation on denitrification. Can. J. Soil Sci., 58, 443-457.

Dhamole P.B., Nair R.R., D'Souza S.F., and Lele S.S., 2007. Denitrification of high strength nitrate waste. Bioresour. Technol., 98, 247-252. https://doi.org/10.1016/j.biortech.2006.01.019

Dinçer A.R. and Kargi F., 2001. Salt inhibition kinetics in nitrification of synthetic saline wastewater. Enzyme Microbial Technol., 28, 661-665. https://doi.org/10.1016/s0141-0229(01)00312-x

Dodla S.K., Wang J.J., De Laune R.D., and Cook R.L., 2008. Denitrification potential and its relation to organic carbon quality in three coastal wetland soils. Sci. Total Environ., 407, 471-480. https://doi.org/10.1016/j.scitotenv.2008.08.022

Gajda A.M., Czyż E.A., and Dexter A.R., 2016. Effects of longterm use of different farming systems on some physical, chemical and microbiological parameters of soil quality. Int. Agrophys., 30, 165-172.

https://doi.org/10.1515/intag-2015-0081
Glatzel S. and Stahr K., 2001. Methane and nitrous oxide exchange in differently fertilized grassland in southern Germany. Plant Soil, 231, 21-35.

Gliński J. and Stępniewski W., 1985. Soil Aeration and its Role for Plants. CRC Press, Boca Raton FL, USA.

Harrison-Kirk T., Beare M.H., Meenken E.D., and Condron L.M., 2013. Soil organic matter and texture affect responses to dry/wet cycles: Effects on carbon dioxide and nitrous oxide emissions. Soil Biol. Biochem., 57, 43-55. https://doi. org/10.1016/j.soilbio.2014.02.021

Hatano R., 2019. Impact of land use change on greenhouse gases emissions in peatland: a review. Int. Agrophys., 33, 167173. https://doi.org/10.31545/intagr/109238

Johnson L.T., Roye T.V., Edgerton J.M., and Leff L.G., 2012. Manipulation of the dissolved organic carbon pool in an agricultural stream: Responses in microbial community structure, denitrification, and assimilatory nitrogen uptake. Ecosystems, 15, 1027-1038. https://doi.org/10.1007/s10021-012-9563-x

Kraft B., Strous M., and Tegetmeyer H.E., 2011. Microbial nitrate respiration - Genes, enzymes and environmental distribution. J. Biotechnol., 155, 104-117. https://doi. org/10.1016/j.jbiotec.2010.12.025

Liptzin D., Whendee L., Silver W.L., and Detto M., 2011. Temporal dynamics in soil oxygen and greenhouse gases in two humid tropical forests. Ecosystems, 14, 171-182. https://doi.org/10.1007/s10021-010-9402-x

Öhlinger R., 1995. Methods is soil physics and chemistry. In: Methods in Soil Biology (Eds F. Schiner, R. Öhlinger, E. Kandeler, R. Margesin). Springer - Verlag Berlin, Heidelberg, 385-390.

https://doi.org/10.1007/978-3-642-60966-4

Patrick W.H. Jr, Mikkelsen D.S., and Wells B.R., 1985. Plant nutrient behavior in flooded soil Fertilizer Technology and Use. Soil Science Society of America, Madison, WI, USA, https://doi.org/10.2136/1985.fertilizertechnology.c6

Patrick W.H. and Jugsujinda A., 1992. Sequential reduction and oxidation of inorganic nitrogen, manganese, and iron in flooded soil. Soil Sci. Soc. Am. J., 56, 1071-1073. https:// doi.org/10.2136/sssaj1992.03615995005600040011x

Pauleta S.R., Dell'Acqua S., and Moura I., 2013. Nitrous oxide reductase. Coordination Chemistry Reviews, 257, 332-349. https://doi.org/10.1016/j.ccr.2012.05.026

Peterson M.E., Curtin D., Thomas S., Clough T.J., and Meenken E.D., 2013. Denitrification in vadose zone material amended with dissolved organic matter from topsoil and subsoil. Soil Biol. Biochem., 61, 96-104. https://doi. org/10.1016/j.soilbio.2013.02.010

Philippot L., Andert J., Jones C. M., Bru D., and Hallin S., 2011. Importance of denitrifiers lacking the genes encoding the nitrous oxide reductase for $\mathrm{N}_{2} \mathrm{O}$ emissions from soil. Global Change Biol., 17, 1497-1504. https://doi.org/10.1111/j.1365-2486.2010.02334.x

Ponnamporuma F.N., 1972. The chemistry of submerged soils. Advances in Agronomy, 24, 29-96.

Rivett M.O., Buss S.R., Morgan F., Smith J.W.N., and Bemment C.D., 2008. Nitrate attenuation in groundwater: A review of biogeochemical controlling processes. Water Res., 42, 4215-4232. https://doi.org/10.1016/j.watres.2008.07.020 
Robertson L.A. and Kuenen J.G., 1991. Physiology of nitrifying and denitrifying bacteria. In: Microbial Production and Consumption of Greenhouse Gases: Methane, Nitrogen Oxides, and Halomethanes (Eds J.E. Rogers, W.B. Whitman). American Society for Microbiology, Washington DC, USA. https://doi.org/10.2134/jeq1994.00472425002300010034x

Ryden J.C., 1983. Denitrification loss from a grassland soil in the field receiving different rates of nitrogen as ammonium nitrate. J. Soil Sci., 34, 355-365. https://doi.org/10.1111/j.1365-2389.1983.tb01041.x

Turn F.T. and Patrick W.H. Jr., 1968. Chemical changes in waterlogged soils as a result of oxygen depletion. In: Int. Congr. Soil Sci. (Ed. J.W. Holmes). Elsevier, 4, Adelaide, New York, USA.

Vor T., Dyckmans J., Loftfield N., Beese F., and Flessa H., 2003. Aeration effects on $\mathrm{CO}_{2}, \mathrm{~N}_{2} \mathrm{O}$ and $\mathrm{CH}_{4}$ emission and leachate composition of forest soil. J. Plant Nutr. Soil Sci., 166, 39-45. https://doi.org/10.1002/jpln.200390010
Wagner-Riddle C., Thurtell G.W., Kidd G.K., Beauchamp E.G., and Sweetman R., 1997. Estimates of nitrous oxide emission from agricultural fields over 28 months. Can. J. Soil Sci., 77, 135-144 . https://doi.org/10.4141/s96-103

Włodarczyk T., 2000. Some of aspects of dehydrogenase activity in soils. Int. Agrophys., 14, 341-354.

Włodarczyk T., Stępniewski W., Brzezińska M., and Stępniewska Z., 2004. Nitrate stability in loess soils under anaerobic conditions - laboratory studies. J. Plant Nutr. Soil Sci., 167, 693-700. https://doi.org/10.1002/jpln.200321253

Włodarczyk T., Stępniewski W., Brzezińska M., and Majewska U., 2011. Various textured soil as nitrous oxide emitter and consumer. Int. Agrophys., 25, 287-297. https://doi.org/10.31545/intagr/106323

Zaman M. and Nguyen M.L., 2010. Effect of lime or zeolite on $\mathrm{N}_{2} \mathrm{O}$ and $\mathrm{N}_{2}$ emissions from a pastoral soil treated with urine or nitrate- $\mathrm{N}$ fertilizer under field conditions. Agric. Ecosyst. Environ., 136, 254-261. https://doi.org/10.1016/j. agee.2009.12.002 